\title{
Heilsugæsla, fjárfesting í heilsu til framtíðar
}

\section{Oddur Steinarsson}

Sérfræðingur í

heimilislækningum og MBA

Framkvæmdastjóri lækninga Heilsugæslu höfuð̋borgarsvæðisins Álfabakka 16 109 Reykjavík

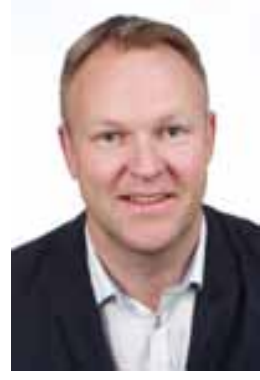

oddur.steinarsson@heilsugaeslan.is

Heilsugæslan hefur ekki verið eins áberandi í pjóðfélagsumræðunni og Landspítalinn. Раð virðist oft vanta skilning á mikilvægi heilsugæslunnar í umræðu bæði meðal pingmanna og almennings í landinu. Рað hefur verið að fjara undan heilsugæslunni á Íslandi og nú er svo komið að pað vantar um 70-80 sérfræðinga í heimilislækningum á landsvísu. Alpjóðaheilbrigðisstofnunin (WHO) hefur lengi bent á mikilvægi starfsemi heilsugæslu í heilbrigðiskerfum landa. Rannsóknir hafa sýnt að lönd sem hafa sterka heilsugæslu ná betri árangri hvað varðar heilbrigði almennings og eru með hagkvæmari heilbrigðiskerfi en samanburðarlönd..$^{1,2}$ Alpjóðaheilbrigðisstofnunin bendir á í skýrslu sinni að efnaðri lönd byggi stóran hluta heilbrigðiskerfis síns á sterkri priðja stigs heilbrigðispjónustu, með ríkum hagsmunum fyrir ólíka aðila, til dæmis lyfja- og lækningatækjaiðnaðinn. . Í sömu skýrslu er bent á mikilvægi pess að fjárfesta í heilsugæslunni, auka teymisvinnu og önnur úrræði í heilsugæslu. Að í heilsugæslunni séu mikil sóknarfæri bæði í forvörnum og snemmgreiningum.

Lífslíkur hafa aukist en á sama tíma hafa ýmsir lífsstílssjúkdómar rutt sér til rúms. Til dæmis hefur fjöldi sykursjúkra á heimsvísu farið úr 30 milljónum manna 1985 í 382 milljónir manna 2013. Spár gera ráð fyrir að fjöldinn geti verið um 552 milljónir manna árið 2030. Kostnaður vegna sykursýki í Bandaríkjunum nam 11\% af heilbrigðisútgjöldum fyrir fullorðna par í landi 2011 og fer hækkandi. ${ }^{3}$ Í Svípjóð hefur heilsugæslan verið efld til pess að taka við peim sem eru með sykursýki af tegund 2.

Hvað varðar geðheilbrigðismál er notkun punglyndislyfja á Íslandi mest af löndum OECD. Árið 2013 fengu 39.000 einstaklingar á Íslandi ávísað punglyndislyfjum og 34.000 fengu ávísað svefnlyfjum og róandi lyfjum að minnsta kosti einu sinni. ${ }^{4}$ Í nokkrum nágrannalöndum okkar er hugræn atferlismeðferð í boði á heilsugæslunni og í Gautaborg, par sem ég hef starfað síðastliðin 6 ár, er skylda að bjóða upp á samtalsmeðferð í allt að 10 skipti í heilsugæslunni, petta vantar sárlega hér.

Heilsugæslan vinnur mjög mikilvægt starf í dag, svo sem í ungbarnavernd og bólusetningum, mæðravernd, heilsuvernd og heimilislækningum. Með breyttu samfélagi, hærra hlutfalli eldri borgara par sem fólk lifir lengur og oftar en ekki með einn eða fleiri undirliggjandi sjúkdóma, er pörfin fyrir öfluga samræmda heilsugæslu á landsvísu mjög mikil. Að heilsugæslan verði efld með aukinni áherslu á heimilislækningar, hjúkrunarfræðinga með viðbótarnám til dæmis í sykursýkismeðferð, næringarráðgjöf og lungnasjúkdómum, sálfræðinga og félagsráðgjafa til viðbótar pví fagfólki sem starfar í dag innan heilsugæslunnar. Að fjölbreytni verði aukin í rekstri, að skjólstæðingar okkar geti valið hvert peir sæki pjónustu og fjármagnið fylgi peim, enda eru peir skattborgararnir sem borga pjónustuna.

Með pessu er hægt að byggja upp öfluga heilsugæslu á landsvísu og ná árangri í forvörnum og snemmgreiningum. Pannig er ráð í tíma tekið og ekki mest áhersla lögð á að bjarga „innistæðum á ögurstundu“, líkt og við pekkjum úr hruninu.

\section{Heimildir}

1. Heath I. A general practitioner for every person in the world. BMJ 2008; 336: 861.

2. The World Health Report 2008 - Primary Health Care (Now More Than Ever).

3. df.org/sites/default/files/Media-Information-Pack.pdf

4. who.int/mediacentre/factsheets/fs236/en/ - nóvember 21014.

5. landlaeknir.is/um-embaettid/frettir/frett/item25254/ Avisunum-a-tauga--og-gedlyf-a-Islandi-hefur-fjolgad-fra2003-til-2013 - nóvember 21014.

Primary Care, Investigating in a Healthier Future Oddur Steinarsson MD, GP, MBA Chief Medical Executive Primary Health Care of the Capital Area Álfabakka 16, 109 Reykjavík

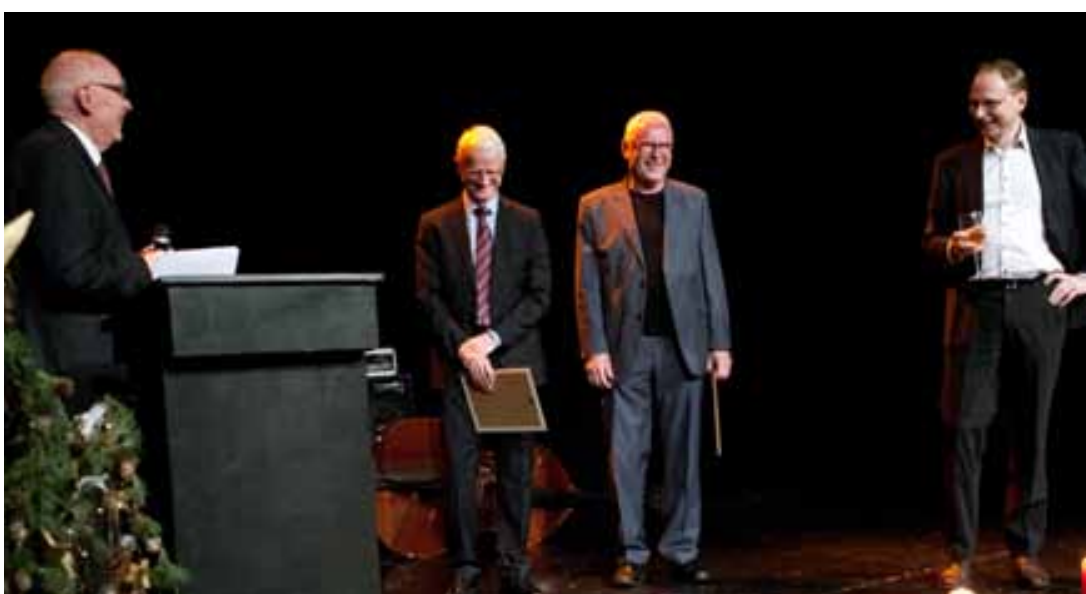

Í lokahófi i İonó eftir XXI ping lyflækna sem haldið var á dögunum í Hörpu. Barna er Pórơur Hardarson í pontu, og Gunnar Sigurơsson og Ástráður B. Hreiðarsson á gódri stund ásamt formanni Félags íslenskra lyflakna, Runólfi Pálssyni. Félagið heiðrađ̃i pá Nick Cariglia, Gunnar og Ástrád fyrir dygg störf og pjónustu í págu lyflakninga hérlendis.

Mynd Hrafnhildur Linnet Runólfsdóttir (læknanemi). 